\title{
Studies on Some Septicemic Bacterial Diseases Affecting Oreochromis Niloticus in Earthen Fish Farm
}

\author{
${ }^{1}$ Viola H. Zaki, Eman. Zahran' ${ }^{2}$ and Rahma E.Awad \\ ${ }^{1.2}$ Department of internal medicine,infectious \& Fish Diseases and \\ Management, Faculty of Veterinary Medicine, Mansoura University. \\ Mansoura, Egypt.
}

\begin{abstract}
This study was carried out on 150 Oreochromis niloticus at Dakhalia governorate within winter and summer seasons of the year 2015. The clinicohistopathological picture and biochemical investigations of the diseased fish were recorded. Sixty fish were infected with various types of bacterial species, of which, (49) fish were infected with Gram-negative bacteria while (11) fish were infected with Gram-positive one. The most common bacterial infection were Aeromonas hydrophila (33\%), Pseudomonas fluorescens (20.5\%), Streptococcus agalactiae (17.8\%), Aeromonas sobria (12.3\%), Vibrio anguillarum (9.5\%) and Vibrio alginolyticus $(6.8 \%)$. The highest total prevalence of bacterial infections was recorded in summer season (39\%) compared to 21 $\%$ in winter. Isolates varied in their antibiotic sensitivity pattern. Inflammatory changes associated with these bacterial diseases were obvious in histopathological sections. Disease conditions were affected by various environmental stressors especially temperature, $\mathrm{pH}$, salinity, ammonia and some heavy metals.
\end{abstract}

Keywords: Oreochromis niloticus, Bacterial diseases, Diagnosis, Pathology, water quality.

\section{Introduction}

The most healthiest and cheapest source of protein is obtained from aquaculture (Nijdam et al, 2012). So, we now trend to increase production of aquatic animal food products more than others $(\boldsymbol{F A O}$, 2012).

Tilapia is the most well known cultured species in all over the world, as it occupies the second prevailing species after carp $(\boldsymbol{F} \boldsymbol{A O}$,
2012). Egypt is ranked 2nd one in production of Tilapia and the 7 th of top ten countries in the total production of fish (El Zokm et al, 2012).

Diseases are considered one of the hazard factors that increase the incidence the Epidemiological aquaculture (Umesh et al, 2008). Any disease usually originates from synergism of the pathogen, host and environment as temperature, $\mathrm{pH}$, 
nitrogenous waste products, salinity and some heavy metals (Madhun et al, 2015).

Bacterial diseases are considered one of the important diseases affecting fish mainly the septicemic bacterial diseases which caused great loss and mortality (Noor ElDeen et al, 2010). The bacterial fish pathogens comprise natural inhabitants of the aquatic environment (El-Refaey, 2013). The current study was investigated the most predominant bacterial diseases in tilapia fish in earthern pond at Dakahlia province.

\section{Materials and Methods:}

Fish:

The study was carried out on 150 freshly captured Oreochromis niloticus of different body weight ranged from (175 to $200 \mathrm{~g}$ ) collected from earthen ponds in private fish farms in Dakahlia governorate in Egypt showing signs of septicemia during the period of December 2014 to July 2015 (winter and summer seasons). Seventy five fish were collected per season.

\section{Bacteriological examination} Sampling and processing

Samples were retrieved from liver, kidney, spleen, gills under fully sterile conditions. Loopfuls were cultured into tryptic soy agar, Aeromoas medium base supplemented with ampicilin, thiosulphate citrate bile salt sucrose agar (TCBS) and Blood agar medium. The inoculated plates were incubated at $25^{\circ} \mathrm{C}$ for $18-48$ hours. Representative numbers of the different colonial types detected on the media were collected from plates and streaked on TSA for purity and identification.

\section{Identification of isolates}

Identification of the obtained bacterial isolates was carried out by performing biochemical and morphological characters using traditional, API $20 \mathrm{E}$ and API strept kits according to (Buller, 2004).

\section{Water quality examination}

In summer, water samples were obtained from various locations from Dakahlia fish farm (2times) in sterile plastic bottles and stored according to methods adopted from (APHA, 2000). Then Physicochemically (Temperature, $\mathrm{pH}$ and salinity), unionized ammonia (NH3) and heavy metals (iron and copper) analysis were measured using Thermometer, Symphony VMR PH meter, Martin conductivity meter, Cintza 101 double beam spectrophotometer and Atomic absorption respectively.

\section{Histopathological studies}

Tissue specimens used for histopathological techniques were obtained from liver, spleen, kidney, gills, intestines and gonads of infected $O$. niloticus. Samples were conserved in $10 \%$ buffered formalin, dehydrated by ethanol solution, then fixed with paraffin, and cut at $5 \mu \mathrm{m}$ thick. Tissue sections were routinely processed 
and stained with Hematoxylin and Eosin ( $\mathrm{H} \& \mathrm{E})$ and finally examined under light microscopy following the criteria reported in Bancroft (1996).

\section{Results}

Naturally infected $O$. niloticus showed: hemorrhagic patches extensively distributed on the external body surface, scales detachment, erosions, fin and tail rot. The gills were congested with prescence of excessive amount of mucus. Some cases showed abdominal distention, ascites exophthalmia (fig1A). On the other hand, postmortem findings revealed paleness of liver, enlargement of gall bladder and congestion of kidney (fig1B).

\section{Isolation and identification of} retrieved bacterial isolates

The phenotypic characteristics of obtained loopfuls from different fish organs showed a total number of seventy three bacterial isolates retrieved from sixty infected fish. Most of obtained isolates were Gram-negative $82.2 \%$ represented as; A. hydrophila $33 \%$ followed by Ps. fluorescens $20.5 \%$, A. sobria $12.3 \%, V$. anguillarum $9.5 \%, V$. alginolyticus $\quad 6.8 \%$.On the other hand Streptococcus agalactiae was the incriminated Gram-positive bacterial pathogens involved in this investigation $\quad 17.8 \% \quad$.Full phenotypic and biochemical characteristics of retrieved isolates are reported in (tables 1, 2) and the prevalence of the different bacterial species is summarized in (table $\mathbf{3}$ ).

Antibiogram sensitivity testing

Isolates differed in their sensitivity pattern according to different antimicrobial agents tested (table4).

The most effective antimicrobial agent tested has been established to be Sulphamethoxazole + Trimethoprim complex $66 \%$. On the other hand, the highest resistances displayed by these bacterial isolates were noticed against novobiocin59 \% and tetracycline $46.5 \%$.

\section{Histopathological lesions}

Inflammatory and necrotic alterations were obvious, also some bacterial colonies were observed in histological sections (Fig. 2).

Degeneration, hemorrhagic necrotic changes were commonly observed in haemopoeitic tissues, liver and kidney. On other hand, gills showed congestion, necrosis and desquamation of epithelial lining of primary gill lamellae and also fusion of secondary gill lamellae.

\section{Water quality parameters}

Disease conditions reported in this study were appeared to be related to stressful environmental condition expressed by unseemly water quality parameters in examined fish farms (Table 5). Investigated fish farms at summer season showed slightly alkaline waters as the $\mathrm{pH}$ values measured about 8.9 and salinity recorded $2 \%$.

Results also demonstrated presence of unfavorable values of some heavy metals such as iron which 
ranged about $2.95 \mathrm{ppm}$ with no presence of copper in summer season. On other hand, levels of some nitrogenous waste products as NH3 was $1 \mathrm{mg} / 1$ which above the permissible level.

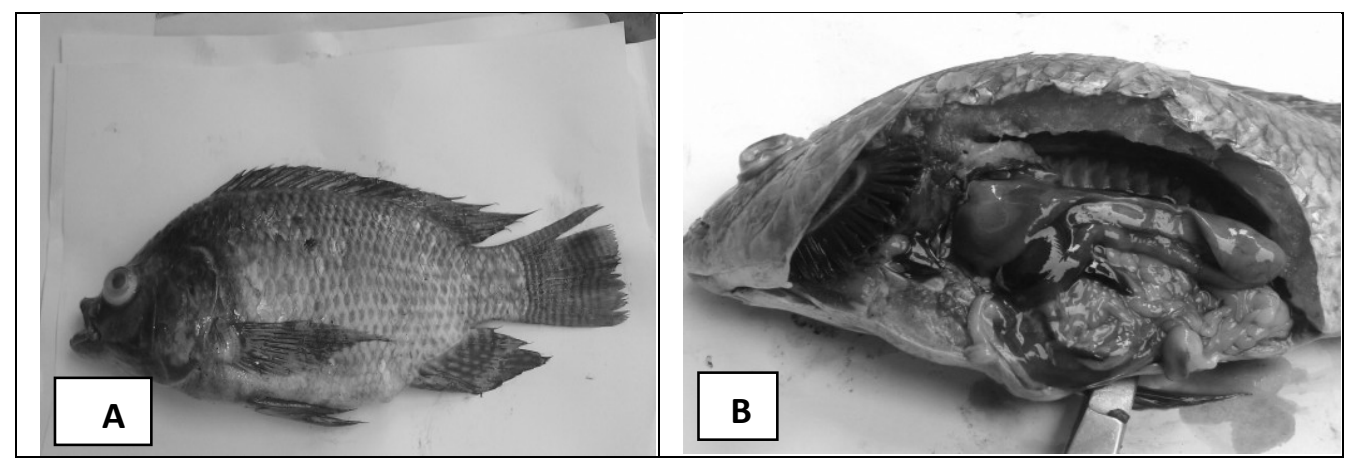

Fig1:(A)Naturally infected tilapia showing haemorrhages on the external body surface and exopthalmia.

(B)Naturally infected tilapia showing paleness of liver,enlargement of gall bladder and congestion of kidney.

Table1: biochemical characteristics of Gram- negative bacterial isolates retrieved from naturally infected $O$. niloticus obtained from API2OE.

\begin{tabular}{|c|c|c|c|c|c|}
\hline Biochemical test & hydrophila & A. sobria & $\begin{array}{c}\text { Ps. } \\
\text { fluorescens }\end{array}$ & V. alginolyticus & V. anguillarum \\
\hline $\begin{array}{c}\text { B-Galactosidase } \\
\text { production (OPNG) }\end{array}$ & + & + & - & - & + \\
\hline $\begin{array}{l}\text { Arginine dinydrolase } \\
\text { production (ADH) }\end{array}$ & + & + & + & - & + \\
\hline $\begin{array}{l}\text { Lysine decarboxylase } \\
\text { production (LDC) }\end{array}$ & + & + & - & + & - \\
\hline $\begin{array}{l}\text { Ornithine decarboxylase } \\
\text { production (ODC) }\end{array}$ & - & - & - & - & - \\
\hline Citrate utilization (CIT) & V & V & V & + & + \\
\hline $\mathrm{H} 2 \mathrm{~S}$ production $(\mathrm{H} 2 \mathrm{~S})$ & + & + & - & - & - \\
\hline Urease production (URE) & - & - & - & $\mathrm{V}$ & - \\
\hline $\begin{array}{c}\text { Tryptophane deaminase } \\
\text { production (TDA) }\end{array}$ & - & - & - & V & - \\
\hline Indole production (IND) & + & + & - & + & - \\
\hline Acetoin production(VP) & + & + & + & - & - \\
\hline $\begin{array}{l}\text { Gelatinase production } \\
\text { (GEL) }\end{array}$ & + & + & - & $\mathrm{V}$ & + \\
\hline Acid from glucose(GLU) & + & + & - & + & + \\
\hline Acid from manitol(MAN) & + & + & - & + & + \\
\hline Acid from inositol(INO) & - & - & - & - & + \\
\hline Acid from Sorbitol(SOR) & V & - & - & V & + \\
\hline $\begin{array}{c}\text { Acid from } \\
\text { rhamnose(RHA) }\end{array}$ & - & - & - & - & - \\
\hline Acid from sucrose(SAC) & + & + & - & + & + \\
\hline $\begin{array}{c}\text { Acid from melibiose } \\
(\mathrm{MEL})\end{array}$ & - & $\mathrm{V}$ & $\mathrm{V}$ & - & - \\
\hline $\begin{array}{l}\text { Acid from amygdalin } \\
\text { (AMY) }\end{array}$ & + & V & - & - & - \\
\hline $\begin{array}{c}\text { Acid from arabinose } \\
\text { (ARA) }\end{array}$ & V & V & - & - & + \\
\hline
\end{tabular}

(+) Positive, (-) Negative, (V) Variable 
Table2: Phenotypic characteristics of $S$. agalactiae obtained from naturally infected $O$. niloticus fish using API strept.

\begin{tabular}{|l|l|l|l|l|l|l|}
\hline $\begin{array}{l}\text { Bacterial } \\
\text { isolates }\end{array}$ & Winter & $\%$ & summer & $\%$ & $\begin{array}{l}\text { Total } \\
\text { isolate }\end{array}$ & $\%$ \\
\hline A.hydrophila & 6 & 30 & 18 & 34 & 24 & 33 \\
\hline A.sobria & 1 & 5 & 8 & 15 & 9 & 12.3 \\
\hline Ps.flurorescens & 11 & 55 & 4 & 7.5 & 15 & 20.5 \\
\hline V.anguillarum & 2 & 10 & 5 & 9.4 & 7 & 9.5 \\
\hline V.alginolyticus & 0 & 0 & 5 & 9.4 & 5 & 6.8 \\
\hline S.agalactia & 0 & 0 & 13 & 24.5 & 13 & 17.8 \\
\hline Total & 20 & $100 \%$ & 53 & $100 \%$ & 73 & $100 \%$ \\
\hline
\end{tabular}

Table3: Prevalence of bacterial isolates obtained from infected fish

\begin{tabular}{|c|c|c|}
\hline \multirow{2}{*}{$\begin{array}{l}\text { Colony } \\
\text { characters }\end{array}$} & Onto marine and TSAS agar & $\begin{array}{l}\text { Small pin point, whitish, rounded } \\
\text { and slightly raised }\end{array}$ \\
\hline & Onto Blood agar & $\beta$ Haemolysis \\
\hline $\begin{array}{l}\text { Microscopical } \\
\text { Examination }\end{array}$ & Gram- stain and cell form & $\begin{array}{l}\text { Gram positive cocci arranged in } \\
\text { short chains }\end{array}$ \\
\hline \multirow{20}{*}{$\begin{array}{l}\text { Biochemical } \\
\text { characteristics } \\
\text { obtained from } \\
\text { API } 20 \text { Strep }\end{array}$} & Voges-Proskauer ( VP ) & + \\
\hline & Hippurate ( hip ) & + \\
\hline & Aesculin ( ESC ) & - \\
\hline & pyrrolidonyl arylamidase ( PYRA ) & - \\
\hline & $\alpha$ galactosidase ( $\alpha$-GAl ) & - \\
\hline & $\beta$ glucuronidase ( $\beta$ GUR ) & Variable \\
\hline & $\beta$ galactosidase ( $\beta$ GAL ) & - \\
\hline & Alkaline phosphatase ( PAL) & + \\
\hline & leucine arylamidase ( LAP) & + \\
\hline & Arginine dihydrolase $(\mathrm{ADH})$ & + \\
\hline & Ribose ( RIB) & + \\
\hline & Arabinose (ARA) & - \\
\hline & Mannitol ( MAN) & - \\
\hline & Sorbitol ( SOR) & - \\
\hline & Lactose ( LAC) & Variable \\
\hline & Trehalose ( TRE) & Variable \\
\hline & Inulin ( INU) & - \\
\hline & Raffinose ( RAF) & - \\
\hline & Amygdalin ( AMD) & Variable \\
\hline & Glycogen ( GLYG) & - \\
\hline
\end{tabular}


Table 4: Antibiogram of obtained bacterial isolates

\begin{tabular}{|c|c|c|c|c|c|c|c|c|c|c|c|c|c|c|c|}
\hline & \multirow[t]{2}{*}{$\begin{array}{r}\text { Con } \\
\mathrm{c} \\
\end{array}$} & \multicolumn{2}{|c|}{$\begin{array}{l}\text { A.hydrophil } \\
\text { a }\end{array}$} & \multicolumn{2}{|c|}{ A.sobria } & \multicolumn{2}{|c|}{$\begin{array}{l}\text { Ps. } \\
\text { fluorescen }\end{array}$} & \multicolumn{2}{|c|}{$\begin{array}{l}\text { V.anguillar } \\
\text { um }\end{array}$} & \multicolumn{2}{|c|}{$\begin{array}{l}\text { V.alginolyti } \\
\text { cus }\end{array}$} & \multicolumn{2}{|c|}{$\begin{array}{r}\text { S.agalacti } \\
a\end{array}$} & \multicolumn{2}{|l|}{ total } \\
\hline & & $\begin{array}{l}N: 2 \\
4\end{array}$ & $\%$ & $\begin{array}{l}\mathrm{N}: \\
9\end{array}$ & $\%$ & $\begin{array}{l}N: 1 \\
5\end{array}$ & $\%$ & $\begin{array}{l}\text { N: } \\
7\end{array}$ & $\%$ & $\mathrm{~N}: 5$ & $\%$ & $\begin{array}{l}N: 1 \\
3\end{array}$ & $\%$ & $\begin{array}{l}\mathrm{N}: 7 \\
3\end{array}$ & $\%$ \\
\hline $\begin{array}{l}\text { Tetracycline } \\
\text { R } \\
\text { I } \\
\text { S }\end{array}$ & $\begin{array}{l}30 \\
\mu \mathrm{g}\end{array}$ & $\begin{array}{l}1 \\
3 \\
20\end{array}$ & $\begin{array}{l}4 \\
12 . \\
5 \\
83\end{array}$ & $\begin{array}{l}4 \\
2 \\
3\end{array}$ & $\begin{array}{l}4 \\
4 \\
2 \\
2 \\
3 \\
3 \\
\end{array}$ & $\begin{array}{l}14 \\
1 \\
-\end{array}$ & $\begin{array}{l}9 \\
3 \\
7 \\
0\end{array}$ & $\begin{array}{l}4 \\
1 \\
2\end{array}$ & $\begin{array}{l}57 \\
14 \\
28 . \\
5\end{array}$ & $\begin{array}{l}2 \\
- \\
3\end{array}$ & $\begin{array}{l}40 \\
0 \\
60\end{array}$ & $\begin{array}{l}9 \\
4 \\
-\end{array}$ & $\begin{array}{l}6 \\
9 \\
3 \\
1 \\
0\end{array}$ & $\begin{array}{l}34 \\
11 \\
28\end{array}$ & $\begin{array}{l}46 . \\
5 \\
15 \\
38\end{array}$ \\
\hline $\begin{array}{l}\text { Novobiocin } \\
\mathrm{R} \\
\mathrm{I} \\
\mathrm{S}\end{array}$ & $\begin{array}{l}30 \\
\mu \mathrm{g}\end{array}$ & $\begin{array}{l}18 \\
4 \\
2\end{array}$ & $\begin{array}{l}75 \\
17 \\
8\end{array}$ & $\begin{array}{l}6 \\
3 \\
-\end{array}$ & $\begin{array}{l}6 \\
7 \\
3 \\
3 \\
0\end{array}$ & $\begin{array}{l}10 \\
3 \\
2\end{array}$ & $\begin{array}{l}6 \\
7 \\
2 \\
0 \\
1 \\
3\end{array}$ & $\begin{array}{l}3 \\
3 \\
1\end{array}$ & $\begin{array}{l}43 \\
43 \\
14\end{array}$ & $\begin{array}{l}- \\
4 \\
1\end{array}$ & $\begin{array}{l}0 \\
80 \\
20\end{array}$ & $\begin{array}{l}6 \\
4 \\
3\end{array}$ & $\begin{array}{l}4 \\
6 \\
3 \\
1 \\
2 \\
3\end{array}$ & $\begin{array}{l}43 \\
21 \\
9\end{array}$ & $\begin{array}{l}59 \\
29 \\
12\end{array}$ \\
\hline $\begin{array}{l}\text { Streptomycin } \\
\text { (S ) } \\
\text { R } \\
\text { I } \\
\text { S } \\
\end{array}$ & $\begin{array}{l}10 \\
\mu \mathrm{g}\end{array}$ & $\begin{array}{l}5 \\
4 \\
15\end{array}$ & $\begin{array}{l}21 \\
17 \\
62 . \\
5\end{array}$ & $\begin{array}{l}5 \\
2 \\
2\end{array}$ & $\begin{array}{l}5 \\
5 \\
2 \\
2 \\
2 \\
2 \\
\end{array}$ & $\begin{array}{l}7 \\
2 \\
6\end{array}$ & $\begin{array}{l}4 \\
7 \\
1 \\
3 \\
4 \\
0 \\
\end{array}$ & $\begin{array}{l}2 \\
1 \\
4\end{array}$ & $\begin{array}{l}28 . \\
5 \\
14 \\
57 \\
\end{array}$ & $\begin{array}{l}3 \\
2 \\
-\end{array}$ & $\begin{array}{l}60 \\
40 \\
0\end{array}$ & $\begin{array}{l}- \\
3 \\
10\end{array}$ & $\begin{array}{l}0 \\
2 \\
3 \\
7 \\
7\end{array}$ & $\begin{array}{l}22 \\
14 \\
37\end{array}$ & $\begin{array}{l}30 \\
19 \\
51\end{array}$ \\
\hline $\begin{array}{l}\text { Sulphamethoxa } \\
\text { zole } \\
\text { +Trimethoprim } \\
\text { (SXT) } \\
\text { R } \\
\text { I } \\
\text { S }\end{array}$ & $\begin{array}{l}25 \\
\mu \mathrm{g}\end{array}$ & $\begin{array}{l}- \\
- \\
24\end{array}$ & $\begin{array}{l}0 \\
0 \\
10 \\
0\end{array}$ & $\begin{array}{l}- \\
3 \\
6\end{array}$ & $\begin{array}{l}0 \\
3 \\
3 \\
6 \\
6\end{array}$ & $\begin{array}{l}4 \\
5 \\
6\end{array}$ & $\begin{array}{l}2 \\
7 \\
3 \\
3 \\
4 \\
0\end{array}$ & $\begin{array}{l}1 \\
5 \\
1\end{array}$ & $\begin{array}{l}14 \\
71 \\
14\end{array}$ & $\begin{array}{l}4 \\
1 \\
-\end{array}$ & $\begin{array}{l}80 \\
20 \\
0\end{array}$ & $\begin{array}{l}- \\
2 \\
11\end{array}$ & $\begin{array}{l}0 \\
1 \\
5 \\
8 \\
5\end{array}$ & $\begin{array}{l}9 \\
16 \\
48\end{array}$ & $\begin{array}{l}12 \\
22 \\
66\end{array}$ \\
\hline $\begin{array}{l}\text { Amoxicillin } \\
\text { AML } \\
\text { R } \\
\text { I } \\
\text { S }\end{array}$ & $\begin{array}{l}10 \\
\mu \mathrm{g}\end{array}$ & $\begin{array}{l}12 \\
10 \\
2\end{array}$ & $\begin{array}{l}50 \\
42 \\
8\end{array}$ & $\begin{array}{l}4 \\
1 \\
4\end{array}$ & $\begin{array}{l}4 \\
4 \\
1 \\
1 \\
4 \\
4\end{array}$ & $\begin{array}{l}3 \\
7 \\
5\end{array}$ & $\begin{array}{l}2 \\
0 \\
4 \\
7 \\
3 \\
3 \\
\end{array}$ & $\begin{array}{l}- \\
6 \\
1\end{array}$ & $\begin{array}{l}0 \\
86 \\
14\end{array}$ & $\begin{array}{l}4 \\
1 \\
-\end{array}$ & $\begin{array}{l}80 \\
20 \\
0\end{array}$ & $\begin{array}{l}3 \\
3 \\
7\end{array}$ & $\begin{array}{l}2 \\
3 \\
2 \\
3 \\
5 \\
4 \\
\end{array}$ & $\begin{array}{l}26 \\
28 \\
19\end{array}$ & $\begin{array}{l}36 \\
38 \\
26\end{array}$ \\
\hline $\begin{array}{l}\text { Doxycycline } \\
\text { (DO) } \\
\text { R } \\
\text { I } \\
\text { S }\end{array}$ & $\begin{array}{l}30 \\
\mu \mathrm{g}\end{array}$ & $\begin{array}{l}10 \\
3 \\
11\end{array}$ & $\begin{array}{l}42 \\
12 \\
46\end{array}$ & $\begin{array}{l}7 \\
1 \\
1\end{array}$ & $\begin{array}{l}7 \\
8 \\
1 \\
1 \\
1 \\
1\end{array}$ & $\begin{array}{l}9 \\
4 \\
2\end{array}$ & $\begin{array}{l}6 \\
0 \\
2 \\
7 \\
1 \\
3\end{array}$ & $\begin{array}{l}2 \\
2 \\
3\end{array}$ & $\begin{array}{l}28 . \\
5 \\
28 . \\
5 \\
43\end{array}$ & $\begin{array}{l}3 \\
- \\
2\end{array}$ & $\begin{array}{l}60 \\
0 \\
40\end{array}$ & $\begin{array}{l}2 \\
9 \\
2\end{array}$ & $\begin{array}{l}1 \\
5 \\
6 \\
9 \\
1 \\
5\end{array}$ & $\begin{array}{l}33 \\
19 \\
21\end{array}$ & $\begin{array}{l}45 \\
26 \\
29\end{array}$ \\
\hline $\begin{array}{l}\text { Kanamycin }(\mathrm{K}) \\
\mathrm{R} \\
\mathrm{I} \\
\mathrm{S}\end{array}$ & $\begin{array}{l}30 \\
\mu \mathrm{g}\end{array}$ & $\begin{array}{l}7 \\
6 \\
11\end{array}$ & $\begin{array}{l}29 \\
25 \\
46\end{array}$ & $\begin{array}{l}1 \\
5 \\
3\end{array}$ & $\begin{array}{l}1 \\
1 \\
5 \\
5 \\
3 \\
3\end{array}$ & $\begin{array}{l}4 \\
3 \\
8\end{array}$ & $\begin{array}{l}2 \\
7 \\
2 \\
0 \\
5 \\
3\end{array}$ & $\begin{array}{l}2 \\
5 \\
-\end{array}$ & $\begin{array}{l}28 . \\
5 \\
71 \\
0 \\
\end{array}$ & $\begin{array}{l}1 \\
1 \\
3\end{array}$ & $\begin{array}{l}20 \\
20 \\
60\end{array}$ & $\begin{array}{l}5 \\
4 \\
4\end{array}$ & $\begin{array}{l}3 \\
7 \\
3 \\
1 \\
3 \\
1\end{array}$ & $\begin{array}{l}20 \\
24 \\
29\end{array}$ & $\begin{array}{l}27 \\
33 \\
40\end{array}$ \\
\hline
\end{tabular}

Table 5: Mean water quality measures in examined fish farm

\begin{tabular}{|l|l|}
\hline Parameters & Summer season \\
\hline Salinity $(\% \mathbf{0})$ & $2 \%$ o \\
\hline Temperature $\left({ }^{\circ} \mathrm{C}\right)$ & 31.5 \\
\hline $\mathrm{pH}$ & 8.9 \\
\hline $\mathrm{NH} 3(\mathrm{mg} / \mathrm{l})$ & 1 \\
\hline Iron $(\mathrm{ppm})$ & 2.95 \\
\hline $\mathrm{Cu}(\mathrm{ppm})$ & 0 \\
\hline
\end{tabular}




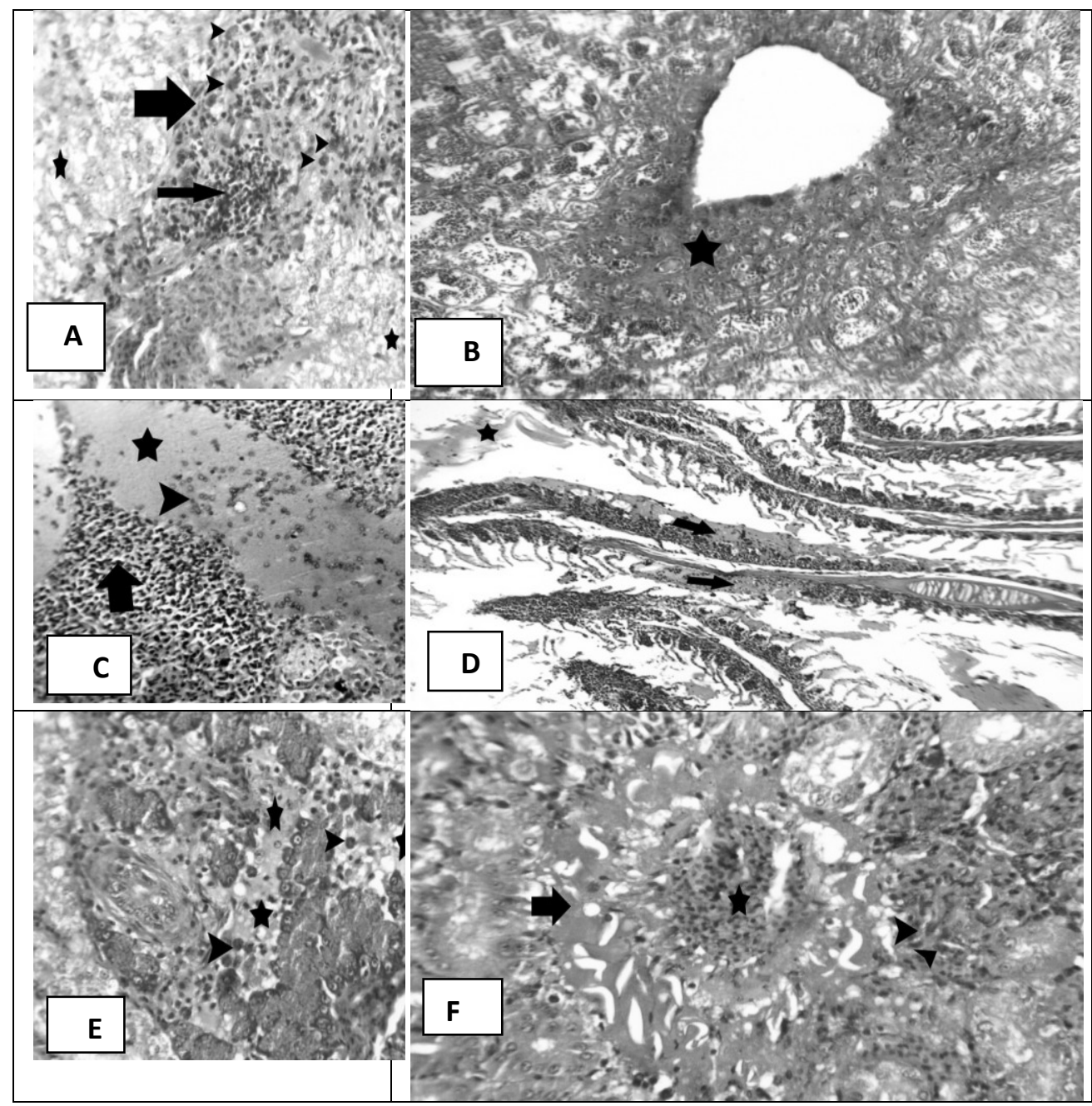

Fig3.A:Liver infected with A.hydrophila shows hydropic degeneration in hepatocytes (asterisks), perivascular fibrosis with mononuclear cells(thin arrow) and eosinophilic granulocytes infiltration(arrowheads)(H\&E, x200). B:Testis infected with A.sobria shows perivascular necrosis and fibrosis(asterisk)(H\&E, x100).

C: Spleen infected with Ps. fluorescence shows bacterial colonies(arrowhead) inside area of necrosis (asterisk) surrounded by leukocytes infiltration(thick arrow) (H\&E, x200).

D: Gills infected with V.anguillarum shows necrosis(arrows) and desquamation of epithelial lining primary gill lamellae(asterisk)(H\&E, $x 100)$. 
E: Liver infected with V.alginolyticus shows focal necrosis(asterisks)and fibrosis in hepatopancreas with few eosinophilic granulocytes infiltration (arrowheads) (H\&E, x200).

F: Caudal kidneys infected with S.agalactia shows congested renal blood vessel (asterisk) with perivascular fibrosis (arrow) and basophilic bacterial colonies trapped inside glomerulus (arrow heads) (H\&E, x200).

\section{Discussion}

Bacterial disease is the most critical sources of disease problems in all types of fish. Specific bacterial pathogens in every type of fish either freshwater or marine are responsible for severe mortalities (Moustafa et al., 2015; Elgendy $e t$ al., 2015).Freshwater aquaculture is considered the main investment in Egypt and other countries (Saad $\boldsymbol{e t}$ al., 2014). Tilapias (Oreochromis sp.) are one of the most important cultured fish in freshwater aquaculture industry (Bostock et al., 2010).

The present study confirmed that tilapia are susceptible to many bacterial pathogens which able to cause diseases. In agreement with other studies relating to freshwater bacterial diseases (Akinbowale et al, 2006; Al-Harbi and Uddin, 2010) most of retrieved bacterial isolates were Gram-negative $82.2 \%$. On the other hand gram-positive bacteria were about $17.8 \%$. Results of bacteriological examination established that A.hydrophila 33\% ,Ps. fluorescens $20.5 \%$, S.agalactia $17.8 \% \quad$,A.sobria $12.3 \%$, V.anguillarum $\quad 9.5 \% \quad$ and V.alginolyticus $6.8 \%$.

Vibrio spp, Ps. fluorescens, S.agalactia and Aeromonas spp were the most common isolated bacteria from this study. These results are similar to those reported by (Tatsuro et al, 2004; Abdel hamid et al, 2013; Elgendy et al, 2013).

A.hydrophila were the most prevalent bacterial pathogens representing $33 \%$ in this study which in accordance to those reported by Al-Laham,et.al (2014) ; Jovanović et al (2015). A. hydrophila recorded $39 \%$ in summer,but $21 \%$ in winter season..Also, A.sobria was reported in summer $(15 \%)$ while winter season $(5 \%)$. This result can be explained as the maximized activity of cytotoxins, hemolysin and enterotoxins above $22{ }^{\circ} \mathrm{C}$ increase the incidence of disease in summer (Krovacek et al, 1991).

Pseudomonads septicemic infections are widly spread.The high frequency of Ps. fluorescens infection was recorded in winter $55 \%$,but in summer $7.5 \%$. This can be explained as proteinases and lipases of $P$. fluorescens have ability to produce at $7 \mathrm{C}$ which trigger incidence of disease in winter season (Wang and Jayarao, 2001).

Vibrosis has great importance in marine water fish but also affect 
freshwater fish (Dyer and Oliver, 2008; Elgendy et al, 2015). Seasonally, the highest prevalence of $V$. anguillarum infection was recorded during the winter and summer $10 \%$ and $9.4 \%$ respectively. On the other hand the highest prevalence of $V$. alginolyticus infection was recorded in summer $9.4 \%$ with no presence in winter. This explained as $V$. alginolyticus may lose its ability to cause disease in cold season (Yan et al, 2007).

Streptococosis has great economic importance due to high fish mortality (Haghighi et al, 2010). S. agalactia has high incidence in summer about $24 \%$ with no prevalence in winter season. This result can be explained that Raising of water temperature (above $26^{\circ} \mathrm{C}$ ) is optimal for increase the prevalence of streptococosis (Mian et al, 2009).

Prevalence of bacterial isolates was higher in summer $53 \%$ than in winter season $20 \%$. This may be explained as higher levels of un ionized ammonia was detected in fish farm water during this period In regards to antibiogram sensitivity testing, freshwater aquaculture is a promising aquaculture sector needing pioneering scientific and technical developments. Excessive using of antibiotics for prophylactic and therapeutic led to increase bacterial resistance (Sarter et al, 2007). Reservoirs of antibiotic resistance can interact between various environmental conditions and transfer of resistant bacteria from animals to humans (Witte, 2000; Vaseeharan et al., 2005).

A.hydrophia isolates showed higher resistance to novobiocin $75 \%$ and Amoxicillin 50\% in compared to other antibiotic tested, On other hand, isolates show intermediate susceptibility to isolates superior susceptibility to Doxycycline $42 \%$.Also, it shows maximum susceptibility in Sulphamethoxazole + Trimethoprim complex $100 \%$,tetracyclin $82 \%$, Streptomycin $\quad 62.5 \% \quad$ and Kanamycin $42 \%$. Results are nearly in accordance with Laith and Najiah (2013) and Al Laham and Al Fadel (2014).

A. sobria isolates demonstrated extreme resistance to Doxycycline $75 \%$, novobiocin $67 \%$, Streptomycin 55\%, tetracycline $44 \%$ were observed in this isolates. Moreover, higher intermediate sensitivity was showed in case of Kanamycin $\mathbf{5 5 . 5 \%}$. On other hand, high susceptibility in Sulphamethoxazole + Trimethoprim complex $66 \%$ was characteristic. Results are nearly in accordance with Guz and Kozinska (2004) and Çiftci et al (2015). In respect to PS. fluorescens, revealed resistance were reported to

$93 \%$,novobiocin

Doxycycline $60 \%$ tetracyclinn 47\%.On contrary, $67 \%$ sensitivity was detected in kanamycin 53\%and Sulphamethoxazole +Trimethoprim combination 40\%,but intermediate resistant to Amoxicillin 
$47 \%$. Results are nearly in accordance with Eissa et al (2010); Foysal et al (2011).

Regarding V.anguillarum, higher sensitivity was recorded in Streptomycin 57\% and Doxycycline 43\%. Furthermore, superior intermediate sensitivity was maximum in Amoxicillin86\% and both Sulphamethoxazole +Trimethoprim combination and Kanamycin $71 \%$, but high resistance to tetracycline $57 \%$. Results are nearly in accordance with Vaseeharan et al (2004); Jayasree et al (2006).

In concern to $V$. alginolyticus strains showed reputed sensitivity to both Kanamycin and tetracycline $60 \%$, but maximum intermediate sensitivity to novobiocin $80 \%$. In addition, isolates exploited superior resistance to both Amoxicillin and Sulphamethoxazole +Trimethoprim reach up to $80 \%$, Doxycycline and Streptomycin about 60\%. Results are nearly in accordance with $\boldsymbol{L i}$ et al (1999); Jayasree et al (2006).

Concerning the antibiogram of S.agalactia isolates displayed higher sensitivity to Sulphamethoxazole+Trimethoprim8 5\%, Streptomycin 77\%, Amoxicillin 54\%. On other hand, isolates displayed prominent resistance was detected in tetracycline $69 \%$, novobiocin $46 \%$, Kanamycin $37 \%$, on contrary, intermediate sensitivity to Doxycycline 69\%. Results are nearly in accordance with Al-
Marzouk et al (2005) ; Abuseliana et al (2010).

In concern to water quality parameters reported in this study, in agreement with Eissa et al (2013); Moustafa et al (2015) unfavorable aquatic environmental condition as low value of water quality parameters increase the prevalence of disease noticed in this study.

In respect to the $\mathrm{pH}$ values, the farm water were slightly alkaline 7.5 in summer season which increase the prevalence of vibrosis reported in this study as the low ph value increase the mucus secretion which increase adhesion of vibrios (Balebona et al, 1995). On the other hand, high $\mathrm{pH}$ increase the toxicity by non ionised ammonia (Ludwig et al, 2007). The high $\mathrm{pH}$ values was (7.5) in summer due to increasing photosynthetic activity, which decrease levels of $\mathrm{Co}_{2}$ and also low levels of dissolved oxygen. These findings are supported by (Goher, 2002).

In regards to salinity, the high salinity noticed in this study (2\%o) which also explained the presence of vibrosis in tilapia.This was in agreement to those reported by $\boldsymbol{A l}$ Sunaiher et al (2010); Abou ElGeit et al (2013). High level of salinity can be explained by increasing evaporation rate in summer (Herbs, 2002).

Regarding ammonia, the ammonia level reported in this investigation ranged $1.1 \mathrm{ppm}$ which was higher than permissible limit $(0.02 \mathrm{mg} / 1)$. This was in agreement to those 
reported by Sachidan and Yajurvedi (2006); Moustafa et al (2015). Increasing level of ammonia triggers the invasion of bacteria especially immumo-suppression fish (Moustafa et al, 2015). While, prolonged low levels of ammonia irritates skin and gills facilitating parasitic infestations and opportunistic bacterial infections (Goher, 2002).

In regard to heavy metals reported in this study, iron ranged $2.95 \mathrm{mg} / 1$ which above the permissible limits $(0.3 \mathrm{mg} / \mathrm{l})$ according to Anzec (2000) with no presence of copper in summer season. This was in agreement in case of levels of iron but not in case of copper levels to those reported by Karadede and Ünlü (2007); Moustafa et al (2015). The high level of iron increases the incidence of some bacterial disease as vibrios since the virulence of vibro spp. enhance with higher iron (Muiño et al, 2001).

In summary the most important bacterial pathogens causing diseases in Orechromis niloticus in the studied farm were $A$. hydrophila, $A$. sobria, Ps. fluorescens, V.anguillarum, $V$. alginolyticus and S.agalactia. Septicemic bacterial infections were related to the noticed unfavorable aquatic environmental stressors. The role of heavy metals including iron in exacerbating bacterial fish diseases is evident. Polluted water weakens the fish host defenses allowing increased opportunities for bacterial infections to affect fish populations.

\section{Acknowledgements}

We are thankful to all members of internal medicine, infectious \& Fish Diseases and Management Department for their valuable support in this research.

\section{References}

Abdel hamid A.M., El-Barbary M.I., and El-Deweny, $M$. E.,(2013): Bacteriological status of ashtoum El-Gamil protected area. Egypt. J. Aquat. Biol. \& Fish., Vol. 17, No. 3:11-23.

Abou El-Geit, E.N, Saad, T.T., Abdo, M. H.,and Zaki ,M. S.,(2013): Microbial infections among some fishes and crustacean species during blooming phenomenon in Qaroun LakeEgypt. Life Science Journal 10(2): 1217-1224.

Abuseliana,A., Daud,H., Abdul Aziz,S., Bejo, S. K., and Alsaid ,M., (2010) Streptococcus agalactiae the Etiological Agent of Mass Mortality in Farmed Red Tilapia (Oreochromis sp.).Journal of Animal and Veterinary Advances;9(20):2640-2646.

Akinbowale ,O.L. , Peng, H., and Barton, M.D. ,(2006): Antimicrobial resistance in bacteria isolated from aquaculture sources in Australia. Journal of Applied Microbiology 100( 5): 1103-1113.

Al Laham,S.A., and Al Fadel,F.M.,(2014): Antibacterial Activity of Various Plants Extracts 
Against Antibiotic-resistant Aeromonas hydrophila.Jundishapur J Microbiol. Jul; 7(7): e11370.

Al-Harbi, A.H., and Uddin, M.N., (2010): Bacterial population of African catfish, Clarias gariepinus (Burchell 1822) cultured in earthen ponds. Journal of Applied Aquaculture 22:187-193.

Al-Marzouk, A., Duremdez, R., Yuasa,K., Sameer, A.Z., AlGharabally ,H., and Munday B., (2005): Fish kill of mullet Lizaklunzingeri in Kuwait Bay: The role of Streptococcus agalactiae and the influence of temperature. In P. Walker, R. Lester andM.G. Bondad-Reantaso (eds). Diseases in Asian Aquaculture V, pp. 143-153. Fish Health Section, Asian Fisheries Society, Manila.

Al-Sunaiher ,A.E., Ibrahim, A.S.S ,and Al-Salamah ,A. A.,(2010): Association of Vibrio Species with Disease Incidencein Some Cultured Fishes in the Kingdom of Saudi Arabia World Applied Sciences Journal 8 (5): 653-660.

Anzec (2000): Australian and New Zealand Guidelines for Fresh and Marine Waters, National Water Quality Management Strategy.Australian and New Zealand Environmental and Conservation Council.

APHA(2000): Standard Methods for the Examination of Water and Wastewater, D.C.

Balebona, M.C., Morinoigos, M.A. and Borrego, J.J., (1995): Role of extracellular products in the pathogenicity of Vibrio strains on cultured gilt-head sea bream, Sparus aurata. Microbiol. SEM., 11: 439-446.

Bancroft, G.D.and Stevens,A.,(1996): Theory and practice of Histological techniques, 4th edition. Edinburgh, Chruchil living stone.

Bostock, J., McAndrew, B., Richards, R., Jauncey, K., Telfer, T., Lorenzen, K., Little, D., Ross, L., Handisyde, N., Gatward, I.,and Corner, R.,( 2010): Aquaculture: global status and trends. PhilosophicalTransactions of the Royal Society B 365: 28972912.

Buller, N.B.,(2004): Bacteria from fish and other aquatic animals: a practical identification manual, Cabi.

Çiftci,A., Onuk,E.E., Çiftci,G., Findik, A., Sogut,M. Ü.,and Gulhan,T.,(2015): The Comparative Analysis of Phenotypic and Genotypic Properties of Aeromonas sobria Strains Isolated from Rainbow Trout (Oncorhynchus mykiss, Walbaum, 1972): Kafkas Univ Vet Fak Derg 21(4): 585-592.

Dyer,B.K., and Oliver, J. D., (2008): The ecology of Vibrio vulnificus, Vibrio cholera, and $V$. parahaemolyticus in North Carolina estuaries. The Journal of Microbiology, 46 (2), 146-153.

Eissa , A.E.,Tharwat, N.A. and Zaki, M.M., (2013): Field assessment of the mid winter mass kills of trophic fishes at Mariotteya stream, Egypt: Chemical and 
biological pollution synergistic model. Chemosphere, 90: 10611068.

Eissa,N.M.E.,AbouEl-

Ghiet,E.N.,Shaheen,A.A.,and

Abbass.A. (2010): Characterization of Pseudomonas Species Isolated from Tilapia "Oreochromis niloticus" in Qaroun and Wadi-ElRayan Lakes, Egypt . Global Veterinaria 5 (2): 116-121

El Zokm, G.M., ELGohary, S.E., and Abd-ElKhalek, D.E., (2012): Studies of some heavy metals in water and sediment in El-Max fish farm, Egypt. World Appl.Sci. J., 18(2): 171-180.

Elgendy, M.Y., (2013): Epizootiological studies on some bacterial infections in marine fishes. Ph.D thesis In: Fish Diseases and Management. Cairo, Faculty of Veterinary Medicine.

Elgendy, M.Y., Moustafa, M. , Gaafar,A.Y. , and Borhan, T. ,( 2015): Impacts of extreme cold water conditions and some bacterial infections on earthen-pond cultured Nile tilapia,Oreochromis niloticus. RJPBCS., 6: 136-145.

El-Refaey,A.M.E.,(2013): Studies on major bacterial diseases affecting fish ; Tilapia Oreochromis niloticus, Catfish, Clarias

gariepinus and mullets in Port Said, Egypt with special references to its pathological

alterations.Researcher,5(2):5-14.

FAO, F., (2012): Yearbook 2010: Fishery and aquaculture Statistics.Food and Agriculture
Organisation of the United Nations, Rome, 78.

Foysal, M.J., Rahman, M.M., and Alam, M., (2011): Antibiotic sensitivity and in vitro antimicrobial activity of plant extracts to pseudomonas fluorescens isolates collected from diseased fish. International Journal of Natural Sciences, 1(4):82-88.

Goher, M. E., (2002): Chemical studies on the preceptation and dissolution of some chemical elements in lake Qarun. Thesis Ph.D Fac. Sien.Al-azhar Univ.

Guz,L.,and Kozinska,A.,(2004): Antibiotic susceptibility of Aeromonas hydrophila and $A$. sobria isolated from farmed carp (Cyprinus Carpiol.). Bull Vet Inst Pulawy 48, 391-395.

Haghighi,S.,Soltani,M.,Gh,N.B.,G ha,M.,and Skall,D.,(2010): Molecular epidemiology of zoonotic streptococcosis/ lactococcosis in rainbow trout (Oncorhynchusmykiss) aquaculture in Iran. Iranian J Microbiol 2:198209.

\section{Hagi,T.,Tanaka,D.,Iwamura,I.}

,and Hoshino,T.,(2004): Diversity and seasonal changes in lactic acid bacteria in the intestinal tract of cultured freshwater fish. Aquaculture 234 (1-4): 335-346.

Herbs,D. B.,(2002): Gradients of salinity stress, environmental stability and water chemistry as a template for defining habitat types and physiological strategies in inland salt water. Hydrobiol., 466: 209-219. 
Jayasree, L. , Janakiram,P., and Madhavi ,R.,(2006):

Characterization of Vibrio spp. Associated with Diseased Shrimp from Culture Ponds of Andhra Pradesh (India). Journal of the World Aquaculture SocietyVolume 37, Issue 4, pages 523-532.

Jovanović,B.,Whitley,E. M., Kimura,K., Crumpton,A., and Palić,D., (2015): Titanium dioxide nanoparticles enhance mortality of fish exposed to bacterial pathogens. Environmental Pollution Volume 203, Pages 153-164.

Karadede,H., and Ünlü,A.E.,(2007): Heavy Metal Concentrations in Water, Sediment, Fish and Some Benthic Organisms from Tigris River, Turkey Environmental Monitoring and Assessment, Volume 131, Issue 1 , pp 3.

Krovacek, K., Faris, A.,and Mansson, I., (1991): Growth of and toxin production by Aeromonas hydrophla and Aeromonas sobria at low temperatures. Int. J. Food Mlcrobiol.13: 165-176.

Laith, A.R., and Najiah,M.,(2013): Aeromonas hydrophila:Antimicrobial

Susceptibility and Histopathology of Isolates from Diseased Catfish, Clarias gariepinus (Burchell) .J Aquac Res Development, 5:215.

Li,J., Yie,J., Foo ,R. W.T., Ling, J. M. L., Xu, H., and Woo,N.Y.S., (1999): Antibiotic Resistance and Plasmid Profiles of Vibrio Isolates from Cultured Silver Sea Bream,
Sparus sarba.Marine Pollution Bulletin 39( 1-12): 245-249.

Ludwig, G.M., M. Hobbs and P. Perschbacher. (2007): Ammonia, $\mathrm{pH}$, and plankton in sunshine bass nursery ponds: the effect of inorganic fertilizer or sodium bicarbonate. North American Journal of Aquaculture 69:80-89.

Madhun,A. S., Biering,E., Isachsen, C. H., Omdal, L. M., Einen, A. C. B.,Wennevik, and V., Svasand, T., (2015): Annual report on health monitoring of wild anadromous salmonids in Norway.Report from the Norwegian Veterinary Institute and the Institute of Marine Research, Bergen, Norway.10:29:58Z.

Mian,G.F.,Godoy,D.T.,Lea,C.A.G .,Yuhara, Y.T., Costa,G.M., and Figueiredo,H.C.P.,

(2009):

Aspects of the natural history and virulence of $S$. agalactiae infection in Nile tilapia. Vet. Microbiol., 136: 180-183.

Moustafa, M. M., Eissa ,A. E., Laila, A. M, Gaafar, A. and Elgendy ， M.Y.(2015): Mass Mortalities in Mari-Cultured European Sea Bass (Dicentrarchus labrax) at Northern Egypt. Research Journal of Pharmaceutical, Biological and Chemical Sciences, vol. 5, issue (4), pp. 95-109.

Muiño,L., Lemos,L.M., and Santos,Y.,(2001): Presence of highaffinity iron uptake systems in fishisolated and environmental strains of Vibrio anguillarum serotype $\mathrm{O} 3$ Federation of European 
Microbiological Societies Volume 202, Issue 1, pages79-83.

Nijdam, D., Rood,T.,and Westhoek, H.,(2012): The price of protein: review of land use and carbon footprints from life cycle assessments of animal food products and their substitutes. Food Policy 37:760-770.

Noor El- Deen, A.E., Atta, N.S., and Abd El Aziz ,M.A.,(2010): Oral Vaccination of Nile Tilapia, Orechromis niloticus, Against Motile Aeromonas Septicemia. Nature and Science, 8(2): 21-26.

Roberts,R.J.(2012):Fishpathology, WileyBlackwell,W.B.Saunders,Phil adelphia, PA.

Saad, T.T, Ketkat,S.A.,and Mohammed, F. A.,(2014): Changes associated with Pseudomonas infection in cultured Oreochromis species and its relations to economic losses of fish production farms.Adv.Res. Agri.Vet.Sci.Vol.1, No. 3: 127-137. Sachidanandamurthy, K.L., and Yajurvedi,H.N.,( 2006): A study on physicochemical parameters of an aquaculture body in Mysore city, Karnataka, India Journal of Environmental Biology 27(4) 615618.

Sarter, S., Nguyen, H.N., Hung, L.T., Lazard ,J. and Montet, D., (2007): Antibiotic resistance in Gram negative bacteria isolated from farmed catfish. Food, Cont., 18: 1391-1396.

Tatsuro, H., Daichi T., Yasutada I. ,and Takayuki H. (2004): Diversity and seasonal changes in lactic acid bacteria in the intestinal tract of cultured freshwater fish. Aquaculture 234 (1-4): 335-346.

Umesh, N.R., Mohan, C.V., Phillips, M.J., Bhat, B.V., Ravi Babu, G., ChandraMohan, A.B. and Padiyar,P.A. (2008): Risk analysis in aquaculture experiencesfrom small-scale shrimp farmers of India.In M.G.BondadReantaso, J.R.Arthur andR.P.Subasinghe

(eds).Understanding and applying risk analysis in aquaculture. $F A O$ Fisheries and Aquaculture Technical Paper.No. 519.Rome,FAO.pp. 247-264.

Vaseeharan ,B. , Lin, J.,and Ramasamy, P.,(2004): Effect of probiotics, antibiotic sensitivity, pathogenicity, and plasmid profiles of Listonella anguillarum-like bacteria isolated from Penaeus monodon culture systems.AquacultureVolume 241, Issues 1-4, Pages 77-91.

Vaseeharan,B.,Ramasamy,P.,Mur uganc,T.and Chen,J.C.,(2005): In vitro susceptibility of antibiotics against Vibrio sp. and Aeromonas $s p$. isolated from Penaeus monodon hatcheries and ponds Int. J.1 of Antimicrob. Agents., 26: 285-291.

Wang, L., and Jayarao, B.M.,( 2001): J Dairy Sci; 84: 1421-1429.

Witte,W.,( 2000): Ecological impact of antibiotics use in animals on different complex microflora environment. Intern. J. Anti. Agent, 14: 321-325. 
Yan, Q., Chen ,Q., Ma ,S., alginolyticus to the intestinal mucus Zhuang, Z., and Wang, X., of large yellow croaker (2007): Characteristics of (Pseudosciaena crocea). adherence of pathogenic Vibrio Aquaculture, 269:21-30.

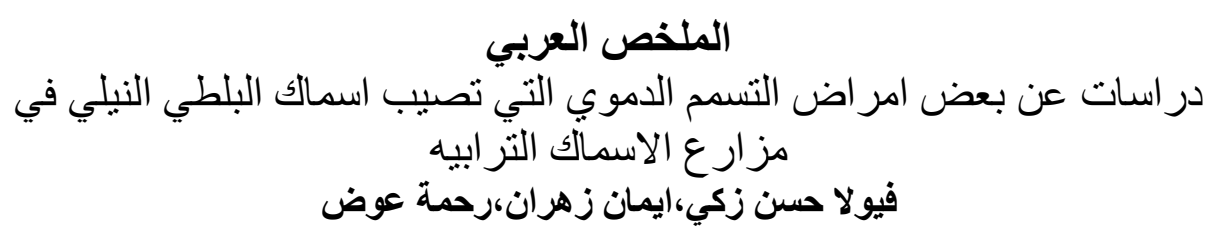

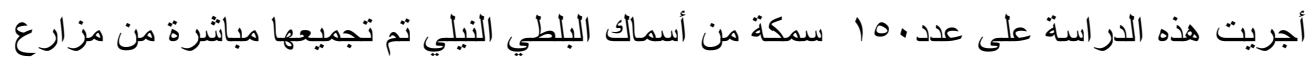

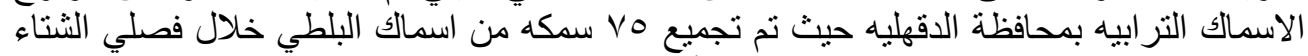

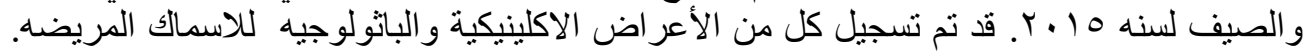

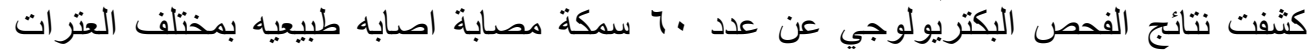

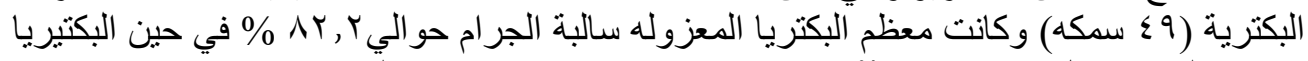

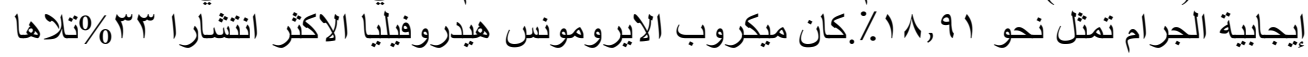

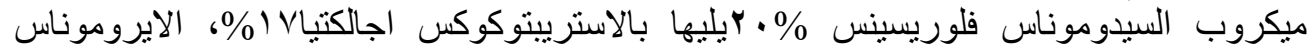

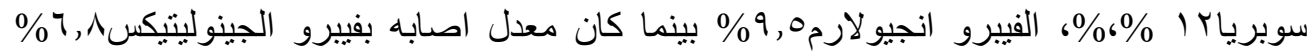

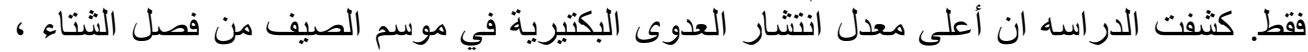

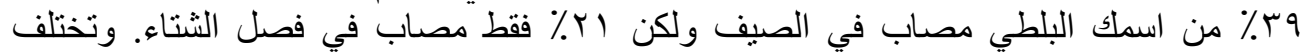

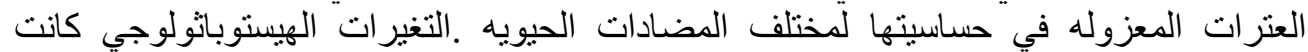

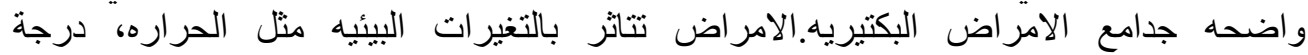

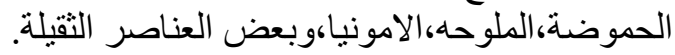

